\title{
Risk and protective factors for depressive symptoms and suicidal behavior in the general population
}

\author{
Fatores de risco e proteção para sintomatologia depressiva e comportamento suicida em população geral
}

Factores de riesgo y protección para sintomatología depresiva y comportamiento suicida en población general

'Universidade Federal de São Paulo. São Paulo, São Paulo, Brazil.

How to cite this article:

Jorgetto GV, Marcolan, JF. Risk and protective factors for depressive symptoms and suicidal behavior in the general population. Rev Bras Enferm. 2021;74(Suppl 3):e20201269. https://doi.org/10.1590/0034-7167-2020-1269

Corresponding author: Giovanna Vallim Jorgetto E-mail: gjorgetto1@gmail.com

EDITOR IN CHIEF: Antonio José de Almeida Filho ASSOCIATE EDITOR: Fátima Helena Espírito Santo

Submission: $12-27-2020$
Approval: 01-30-2021

\begin{abstract}
Objective: To analyze the participants' perception of risk and protective factors for depressive symptoms and their relationship with suicidal behavior in a general adult population. Method: Exploratory-descriptive, qualitative research, using Content Analysis. Interviews with 200 participants over 18 years old, domiciled in Poços de Caldas/MG, between January 2017 and October 2018. Results: Risk factors were sadness, loneliness, problematic family relationships, losses/difficulties in emotional relationships, unemployment/financial difficulties, depressive symptoms, worsening of the feeling of depression, inability to frustration, problems in experiencing spirituality. Protective factors were family, emotional relationships, and spirituality. Suicidal behavior was related to the severity of depression, feelings of hopelessness, psychiatric comorbidities, and unemployment. Final considerations: Perception of risk factors was linked to family problems, sadness, loss of emotional relationships, unemployment, loneliness, and inability to experience frustrations; and the protective ones perceived were family and spirituality. There was a relationship between depressive symptoms and suicidal behavior. Descriptors: Depression; Suicidal Behavior; Mental Health; Risk Factors; Protection Factors.
\end{abstract}

\section{RESUMO}

Objetivo: Analisar a percepção dos participantes sobre fatores de risco e de proteção para sintomatologia depressiva e sua relação com comportamento suicida em população geral adulta. Método: Pesquisa exploratório-descritiva, qualitativa, usando Análise de Conteúdo. Entrevistas com 200 participantes acima de 18 anos, domiciliados em Poços de Caldas/ MG, entre janeiro de 2017 e outubro de 2018. Resultados: Fatores de risco foram tristeza, solidão, relações familiares problemáticas, perdas/dificuldades nos relacionamentos afetivos, desemprego/dificuldades financeiras, sintomatologia depressiva, piora na sensação de depressão, inabilidade para frustração, problemas na vivência da espiritualidade. Fatores de proteção foram família, relacionamentos afetivos e espiritualidade. Comportamento suicida foi relacionado à severidade da depressão, sentimentos de desesperança, comorbidades psiquiátricas e desemprego. Considerações finais: Percepção dos fatores de risco atrelouse a problemas familiares, tristeza, perda de relacionamentos afetivos, desemprego, solidão e inabilidade em vivenciar frustrações; e os de proteção percebidos foram família e espiritualidade. Houve relação entre sintomatologia depressiva e comportamento suicida. Descritores: Depressão; Comportamento Suicida; Saúde Mental; Fatores de Risco; Fatores de Proteção.

\section{RESUMEN}

Objetivo: Analizar percepción de participantes sobre factores de riesgo y de protección para sintomatología depresiva y su relación con comportamiento suicida en población general adulta. Método: Investigación exploratorio-descriptiva, cualitativa, usando Análisis de Contenido. Entrevistas con 200 participantes adultos, domiciliados en Poços de Caldas/ MG, entre enero de 2017 y octubre de 2018. Resultados: Factores de riesgo fueron tristeza, soledad, relaciones familiares problemáticas, pérdidas/dificultades en relaciones afectivas, desempleo/dificultades financieras, sintomatología depresiva, empeora en sensación de depresión, inhabilidad para frustración, problemas en la vivencia de espiritualidad. Factores de protección fueron familia, relaciones afectivas y espiritualidad. Comportamiento suicida relacionado a la severidad de la depresión, sentimientos de desesperanza, comorbilidades psiquiátricas y desempleo. Consideraciones finales: Percepción de los factores de riesgo se relacionaron a problemas familiares, tristeza, pérdida de relaciones afectivas, desempleo, soledad e inhabilidad en experimentar frustraciones; $y$ los de protección percibidos fueron familia y espiritualidad. Hubo relación entre sintomatología depresiva y comportamiento suicida. Descriptores: Depresión; Comportamiento Suicida; Salud Mental; Factores de Riesgo; Factores de Protección. 


\section{INTRODUCTION}

Depression is estimated to be the second leading cause of life years lost due to disability worldwide (4.3\%) and by 2030 it will occupy the first cause of disability and the second largest cause of years lived with disability in the world ${ }^{(1)}$, reaching women (13.4\%) more than men $(8.3 \%)^{(2)}$.

The failure to detect patients with mild and moderate levels favors the worsening of depression, with important effects on the ability to study, work and have a good quality of life ${ }^{(3)}$. Detecting cases of depression has been effective in reducing the number of subsequent visits, shortening the duration of the episode and mitigating its long-term effects ${ }^{(4-5)}$.

According to the estimates of the World Health Organization (WHO), currently about 350 million people are expected to suffer from depression ${ }^{(1)}$, and it presents in its severe condition, with or without psychotic symptoms, an intimate relationship with suicidal behavior ${ }^{(1)}$. Data published by WHO between 2006 and 2010 also pointed out that the clinical picture of severe depressive disorder is the factor that most predisposes to suicide ${ }^{(2)}$.

Suicide is usually the tragic outcome of psychiatric disorders such as affective disorders, psychotic disorders and use of psychoactive substances. In almost $90 \%$ of suicide cases, there is a diagnosis of mental disorder or abuse of psychoactive substances ${ }^{(1,6)}$.

Suicidal ideation without attempted suicide is more common than suicide attempts themselves, but should not be underestimated, as $17 \%$ of patients with severe depression attempt suicide at least once. The highest suicide rate occurs effectively among patients with depression ${ }^{(1,6)}$.

\section{OBJECTIVE}

To analyze the participants' perception of risk and protective factors for depressive symptoms and their relationship with suicidal behavior in a general adult population.

\section{METHODS}

\section{Ethical aspects}

The research took place after approval by the Research Ethics Committee of the Federal University of São Paulo, with a favorable opinion, respecting the research legislation in human beings, according to Resolution 466/12. All participants were informed about the purpose of the study, their rights and signed the Free and Informed Consent Form. Anonymity was preserved using codes (E1, E2, E3 ... E200).

\section{Theoretical-methodological framework}

The theoretical framework of Thematic Content Analysis ${ }^{(7)}$ was used, which translates into a set of communication analysis techniques in order to obtain, by systematic and objective procedures, the description of the content of the messages.

\section{Study type}

Exploratory-descriptive, qualitative study, based on the theoretical framework of Thematic Content Analysis(7), using the
Consolidated Criteria for Reporting Qualitative Research (COREQ) checklist as a key script for reporting qualitative research in a general adult population of city of Poços de Caldas/MG.

\section{Study scenario}

The survey was conducted in a medium-sized city in the south of the state of Minas Gerais, with an estimated 167,897 inhabitants and a demographic density of 305.9 inhabitants per $\mathrm{km}^{2(8)}$.

\section{Study participants}

The population was residents and domiciled in the city of Poços de Caldas/MG, with the inclusion criteria: participants of both sexes; being over 18 years old; be a resident and domiciled in Poços de Caldas/MG for 12 months or more; and present cognitive conditions to participate in the study. The exclusion criteria were: being under 18 years old; be resident and domiciled in Poços de Caldas/MG for less than 12 months; not having cognitive conditions to participate in the study; and refuse to participate.

The stratified non-probabilistic and random sample was defined by convenience in 200 participants, chosen randomly from the center and the three cardinal points of the city (South, East and West), maintaining the proportion of 50 participants per geographical area. The number of interviews was divided by the number of neighborhoods in the regions, taking care to ensure an equal division of participants by neighborhood. The street in each neighborhood was drawn and the collection started with the lowest street number on the street. After the interview was conducted, the next approach was carried out across the street and, thus, successively respecting the alternation of two houses between one participant and another. There was no withdrawal during the interview. Data was collected randomly on weekdays, including Saturday and Sunday, during the morning, afternoon, and night, with a view to the reliability of the results obtained.

\section{Data collection and organization}

Data collection took place between January 2017 and October 2018. The instruments for data collection used were psychometric scales for depressive symptoms, applied in the following order: Beck Depression Inventory, Hamilton Depression Rating Scale and Hamilton Depression Scale. Assessment for Montgomery-Asberg Depression. For each item, the participant was asked to answer which alternative best described their feelings in the last week, including the day of the survey.

The interview was then followed through the application of a semi-structured questionnaire with items formulated based on the objective of the research and referring to the sociodemographic profile of the participants, data on the history of depression and suicidal behavior and two guiding questions of free answer that enabled other questions and approaches to emerging issues, which are: Describe what factors you believe may put you at risk and those that can protect you from becoming depressed or suicidal; and Describe your perception of depressive symptoms in relation to suicidal behavior.

The interviews took place at the participant's home, in a private manner, which guaranteed the confidentiality of the information. They were audio-recorded for the full transcription and lasted 
an average of one hour and 30 minutes, and after the responses, individuals in situations of vulnerability and risk of suicide were referred to health facilities. The interviews were conducted by the main author of the manuscript, who underwent training for this application, with no previous contact with the participants.

\section{Data analysis}

The data collected through the interviews, after signing the Free and Informed Consent Form (ICF) in two copies, were coded by Thematic Content Analysis ${ }^{(7)}$, covering the three phases: Preanalysis; Exploration of the material; and Treatment of results, inference and interpretation. Two thematic categories and thematic units were determined:

Thematic category 1: Participants' perception of depressive symptoms and suicidal behavior from the perspective of risk and protection factors, containing the thematic units on 1) Perception of risk factors to depressive symptoms and suicidal behavior; and 2) Perception of protective factors for depressive symptoms and suicidal behavior;

Thematic category 2: Participants' perception of the relationship between depressive symptoms and suicidal behavior.

Regarding the quantitative data regarding the participants'sociodemographic profile, the statistical significance was determined based on Fisher's exact test, considering as statistically significant results with a probability of type I error, less than $5 \%(p<0.05)$.

\section{RESULTS}

\section{Sociodemographic characterization of study participants}

Table 1 shows the distribution of participants according to sociodemographic aspects according to the presence or absence of depressive symptoms detected by psychometric scales.

Table 1 - Socioeconomic and demographic characterization of participants with and without depressive symptoms and statistical analysis, Poços de Caldas, Minas Gerais, Brazil, 2019, N = 200

\begin{tabular}{|c|c|c|c|c|}
\hline Variables & Total (\%) & $\begin{array}{l}\text { Presence of depressive } \\
\text { symptoms (\%) }\end{array}$ & $\begin{array}{l}\text { Absence of depressive } \\
\text { symptoms (\%) }\end{array}$ & $p$ value \\
\hline \multicolumn{5}{|l|}{ Sex } \\
\hline Female & $122(61.0)$ & $57(78.1)$ & $65(51.2)$ & $<0.001$ \\
\hline Male & $78(39.0)$ & $16(21.9)$ & $62(48.8)$ & \\
\hline \multicolumn{5}{|l|}{ Age group } \\
\hline $18-28$ & $43(21.5)$ & $12(16.4)$ & $31(24.4)$ & 0.174 \\
\hline $29-39$ & $52(26.0)$ & $22(30.1)$ & $30(23.6)$ & \\
\hline $40-50$ & $40(20.0)$ & $12(16.4)$ & $28(22.0)$ & \\
\hline $51-61$ & $26(13.0)$ & $14(19.2)$ & $12(9.4)$ & \\
\hline $62-72$ & $28(14.0)$ & $11(15.1)$ & $17(13.4)$ & \\
\hline $73-83$ & $11(5.5)$ & $02(2.7)$ & $09(7.1)$ & \\
\hline \multicolumn{5}{|l|}{ Color } \\
\hline White & $168(84.0)$ & $67(91.8)$ & $101(79.5)$ & 0.056 \\
\hline Brown & $27(13.5)$ & $05(6.8)$ & $22(17.3)$ & \\
\hline Black & $05(2.5)$ & $01(1.4)$ & $04(3.1)$ & \\
\hline \multicolumn{5}{|l|}{ Religion } \\
\hline Catholic & $138(69.0)$ & $47(64.4)$ & $91(71.7)$ & 0.196 \\
\hline Evangelical & $43(21.5)$ & $18(24.7)$ & 25 (19.7) & \\
\hline Without religion & $07(3.5)$ & $02(2.7)$ & $05(3.9)$ & \\
\hline Spiritist & $04(2.0)$ & ------ & $04(3.1)$ & \\
\hline Adventist & $02(1.0)$ & $02(2.7)$ & ---- & \\
\hline Atheist & $02(1.0)$ & - & $02(1.6)$ & \\
\hline Not declared & $04(-)$ & $0 \overline{04(-)}$ & - & \\
\hline \multicolumn{5}{|l|}{ Civil status } \\
\hline Married & $124(62.0)$ & $39(53.4)$ & $85(66.9)$ & 0.156 \\
\hline Not married & $40(20.0)$ & $15(20.5)$ & $25(19.7)$ & \\
\hline Divorced & $15(7.5)$ & $08(11.0)$ & $07(5.5)$ & \\
\hline Widow(er) & $14(7.0)$ & $06(8.2)$ & $08(6.3)$ & \\
\hline Stable union & $06(3.0)$ & $04(5.5)$ & $02(1.6)$ & \\
\hline Separate & $01(0.5)$ & $01(1.4)$ & ----- & \\
\hline \multicolumn{5}{|l|}{ Children } \\
\hline Yes & $153(76.5)$ & $67(91.8)$ & $86(67.7)$ & $<0.001$ \\
\hline No & $47(23.5)$ & $06(8.2)$ & $41(32.3)$ & \\
\hline \multicolumn{5}{|l|}{ Number of children } \\
\hline 1 & $49(24.5)$ & $19(26.0)$ & $30(23.6)$ & 0.860 \\
\hline 2 & $92(46.0)$ & $32(43.8)$ & $60(47.2)$ & \\
\hline 3 & $29(14.5)$ & $10(13.7)$ & $19(15.0)$ & \\
\hline 4 & $19(9.5)$ & 09 (12.3) & $10(7.9)$ & \\
\hline 5 & $09(4.5)$ & $03(4.1)$ & $06(4.7)$ & \\
\hline More than 6 & $02(1.0)$ & ----- & $02(1.6)$ & \\
\hline
\end{tabular}




\begin{tabular}{|c|c|c|c|c|}
\hline Variables & Total (\%) & $\begin{array}{l}\text { Presence of depressive } \\
\text { symptoms (\%) }\end{array}$ & $\begin{array}{l}\text { Absence of depressive } \\
\text { symptoms (\%) }\end{array}$ & $p$ value \\
\hline \multicolumn{5}{|l|}{ Educational level } \\
\hline Illiterate & $03(1.5)$ & $01(1.4)$ & $02(1.6)$ & 0.001 \\
\hline Functional illiterate & $02(1.0)$ & ----- & $02(1.6)$ & \\
\hline Incomplete elementary school & $58(29.0)$ & $20(27.4)$ & $38(29.9)$ & \\
\hline Complete primary education & $19(9.5)$ & $12(16.4)$ & $07(5.5)$ & \\
\hline Incomplete high school & $20(10.0)$ & $14(19.2)$ & $06(4.7)$ & \\
\hline Complete high school & $40(20.0)$ & $12(16.4)$ & $28(22.0)$ & \\
\hline Incomplete higher education & $09(4.5)$ & $01(1.4)$ & $08(6.3)$ & \\
\hline Complete higher education & $41(20.5)$ & $13(17.8)$ & $28(22.0)$ & \\
\hline Specialization & $08(4.0)$ & ------ & $08(6.3)$ & \\
\hline \multicolumn{5}{|c|}{ Number of people residing in the household } \\
\hline 1 & $21(10.5)$ & $09(12.3)$ & $12(9.4)$ & 0.407 \\
\hline 2 & $48(24.0)$ & $17(23.3)$ & $31(24.4)$ & \\
\hline 3 & $53(26.5)$ & $14(19.2)$ & $39(30.7)$ & \\
\hline 4 & $49(24.5)$ & $19(26.0)$ & $30(23.6)$ & \\
\hline 5 & $16(8.0)$ & 09 (12.3) & $07(5.5)$ & \\
\hline 6 & $09(4.5)$ & $03(4.1)$ & $06(4.7)$ & \\
\hline 7 & $04(2.0)$ & $02(2.7)$ & $02(1.6)$ & \\
\hline \multicolumn{5}{|l|}{ Who you live with } \\
\hline Companion/husband/wife/children & $124(62.0)$ & $39(53.4)$ & $85(66.9)$ & 0.361 \\
\hline Sons & $36(18.0)$ & $14(19.2)$ & $22(17.3)$ & \\
\hline Friends & $11(5.5)$ & $05(6.8)$ & $06(4.7)$ & \\
\hline Siblings & $07(3.5)$ & $03(4.1)$ & $04(3.1)$ & \\
\hline Grandchildren & $06(3.0)$ & $03(4.1)$ & $03(2.4)$ & \\
\hline Alone & $16(8.0)$ & $09(12.3)$ & $07(5.5)$ & \\
\hline \multicolumn{5}{|l|}{ Work activity/Profession } \\
\hline Unpaid activity & $51(25.5)$ & $20(27.4)$ & $31(24.4)$ & 0.163 \\
\hline Retired & $37(18.5)$ & $14(19.2)$ & $23(18.1)$ & \\
\hline Industry worker & $15(7.5)$ & $06(8.2)$ & $09(7.1)$ & \\
\hline Trade worker & $16(8.0)$ & $04(5.5)$ & $12(9.4)$ & \\
\hline Domestic workers & $08(4.0)$ & $01(1.4)$ & $07(5.5)$ & \\
\hline Education Professional & $08(4.0)$ & $02(2.7)$ & $06(4.7)$ & \\
\hline \multicolumn{5}{|l|}{ Individual income } \\
\hline Has no income & $23(11.5)$ & $22(30.1)$ & $01(0.8)$ & $<0.001$ \\
\hline Up to 2 minimum wages & $75(37.5)$ & $34(46.6)$ & $41(32.3)$ & \\
\hline From 2 to 5 minimum wages & $76(38.0)$ & $15(20.5)$ & $61(48.0)$ & \\
\hline Above 5 minimum wages & $20(10.0)$ & $02(2.7)$ & $18(14.2)$ & \\
\hline Did not inform & $06(3.0)$ & ----- & $06(4.7)$ & \\
\hline \multicolumn{5}{|l|}{ Family income } \\
\hline Has no income & $10(5.0)$ & ------ & $10(7.9)$ & 0.073 \\
\hline Up to 2 minimum wages & $62(31.0)$ & $23(31.5)$ & $39(30.7)$ & \\
\hline From 2 to 5 minimum wages & $101(50.5)$ & $39(53.4)$ & $62(48.8)$ & \\
\hline Above 5 minimum wages & $27(13.5)$ & $11(15.1)$ & $16(12.6)$ & \\
\hline \multicolumn{5}{|l|}{ Unemployed } \\
\hline Yes & $23(11.5)$ & $22(30.1)$ & $01(0.8)$ & $<0.001$ \\
\hline No & $177(88.5)$ & $51(69.9)$ & $126(99.2)$ & \\
\hline \multicolumn{5}{|l|}{ Social media use } \\
\hline Facebook & $177(88.5)$ & $50(68.5)$ & $127(100.0)$ & $<0.001$ \\
\hline Instagram & 39 (19.5) & $07(9.6)$ & $32(25.2)$ & 0.009 \\
\hline Twitter & $03(1.5)$ & $01(1.4)$ & $02(1.6)$ & 1.000 \\
\hline Does not have & ----- & $21(28.8)$ & ----- & $<0.001$ \\
\hline \multicolumn{5}{|l|}{ Recreation/Leisure } \\
\hline Being with friends & $72(36.0)$ & $24(32.9)$ & $48(37.8)$ & 0.312 \\
\hline Walk & $51(25.5)$ & $23(31.5)$ & $28(22.0)$ & \\
\hline To dance & $37(18.5)$ & $10(13.7)$ & $27(21.3)$ & \\
\hline Does not have & $40(20.0)$ & $16(21.9)$ & $24(18.9)$ & \\
\hline
\end{tabular}

Table 2 lists the data regarding the presence and intensity of depressive symptoms, according to the results of the application of psychometric scales for participants with and without a previous diagnosis of depression.

We highlight that there was a third of the participants over 61 years old with positive scores for depressive symptoms, mainly in mild and moderate intensity, detected by the psychometric scales used in this study. Suicidal behavior was present in all participants who had depressive symptoms indicated by the scales and more pronounced in those who had higher scores in groups with moderate and severe levels of intensity.

After transcribing the guiding questions, the participants'speeches were analyzed; and, determined units of record with meaning that encompass the objectives proposed for this study and other points of interest. Thus, two thematic categories emerged, one related to the perception of risk and protective factors for depressive symptoms and suicidal behavior; and the second on the relationship between depressive symptoms and suicidal behavior, as follows. 
Table 2 - Presence and intensity of depressive symptoms according to psychometric scales for depression, Poços de Caldas, Minas Gerais, Brazil, $2020, N=200$

\begin{tabular}{|c|c|c|c|}
\hline Variables & Total (\%) & $\begin{array}{c}\text { Presence of previous } \\
\text { depressive symptoms } \\
\text { (\%) }\end{array}$ & $\begin{array}{c}\text { Absence of previous } \\
\text { depressive symptoms } \\
\text { (\%) }\end{array}$ \\
\hline \multicolumn{4}{|l|}{$\mathrm{BDI}$ * } \\
\hline Light & $37(50.7)$ & 34 (54.8) & $03(27.3)$ \\
\hline Moderate & $27(37.0)$ & $22(35.5)$ & 05 (45.5) \\
\hline Serious & 09 (12.3) & $06(9.7)$ & $03(27.3)$ \\
\hline \multicolumn{4}{|l|}{ HAM-D* } \\
\hline Light & 35 (47.9) & $32(51.6)$ & $03(27.3)$ \\
\hline Moderate & $27(37.0)$ & $23(37.1)$ & $04(36.4)$ \\
\hline Serious & $11(15.1)$ & $07(11.3)$ & 04 (36.4) \\
\hline \multicolumn{4}{|l|}{ MADRS* } \\
\hline Light & 35 (47.9) & $32(51.6)$ & $03(27.3)$ \\
\hline Moderate & $27(37.0)$ & $23(37.1)$ & 04 (36.4) \\
\hline Serious & $11(15.1)$ & $07(11.3)$ & 04 (36.4) \\
\hline \multicolumn{4}{|c|}{$\begin{array}{l}\text { Note*: BDI= Beck Depression Inventory II, HAM-D= Hamilton Depression Rating Scale, MADRS= } \\
\text { Montgomery-Asberg Depression Scale }\end{array}$} \\
\hline
\end{tabular}

\section{Thematic unit 1 - Perception of risk factors for depressive symptoms and suicidal behavior}

Regarding the risk factors for depressive symptoms, problems emerged in the speeches, mostly related to the difficulty in the bonds and relationships in the family, aggravated by the use of alcohol and other drugs and unemployment; sadness and loneliness regarding questions about the physical absence of significant people and disappointment regarding the affective relationship; real and anticipatory losses, with the death of significant people being verbalized; feedback from depressive symptoms; inability to experience frustrations throughout life; and problems with spirituality.

With regards to loneliness, it appears that the speeches were related to the inability to live alone, linked to the feeling of guilt, impairment in social interaction, having a family and not having close contact with family members, accentuated by the installed depression.

I get depressed when I think about being alone, without anyone. (E13)

What has been making me depressed, and I've been diagnosed with depression, is the lack of living with other people; I end up isolating myself and moving away from people, because I can't be around many people. I don't feel like dying, because I believe it wouldn't solve a lot, it would only increase the problems for my whole family. (E16)

When I feel alone, feeling that everything goes wrong, feeling guilty. When I have these feelings, I feel like disappearing and dying. (E18)

What makes me depressed is when I feel alone, when my family doesn't care about me, they don't care if I'm okay, whether I'm alive or dead. (E71)

Regarding sadness, this was linked to the difficulty in carrying out activities of daily living, rumination of ideas, rejection, hopelessness, pain, frustrations in affective relationships, low self-esteem, and hopelessness.

I feel sad when I can't even do my homework, I feel like dying, yes, I confess... I feel that emptiness inside my chest. (E10)

I believe it is nervousness and sadness. The person puts something on his head that does not exist and becomes depressed and sad. Often comes the desire to die. (E17)

What makes me depressed are some things that happen around me and make me sad, for example when they reject me and turn away from me, I believe that the problem is me, even if it is not. It makes me depressed. (E20)

There is nothing lately that makes me happy. I simply live. Life makes me depressed. (E23)

Problems in family relationships regarding the use of drugs by close relatives, separation, and frustration of expectations in affective relationships, problems of children and relationships with them and health problems of family members emerged from the discourse.

What makes me depressed is seeing my son's situation in drinks, drugs, makes me see how cruel the world is. (E6)

What makes me depressed is problems at home. I am suffering from the separation of my eldest son. My daughter-in-law and the children are suffering a lot for his betrayal. Now he's even living with the other woman. I think this woman made him macumba. (E19)

In the content of the statements below, the real and anticipatory losses caused by death (death of the son, death of the husband due to cancer, suicide of the father, violent death of the brother, murder of the ex-husband, fear of losing a loved one) stand out.

Everything makes me depressed! After my son's death, I am sadder every day. I think dying would be the best for me and everyone. At the moment, nothing is good [...]. There is no good day now. Everything sad and gray. (E7)

Loss of someone I really like. Lack of someone. Sometimes I feel like crying when I remember my brother who was murdered. He is sorely missed. (E11)

I don't remember when I was happy anymore. I think everything is not funny. After my father committed suicide I don't remember being happy anymore. (E40)

Issues related to unemployment or financial difficulties or both emerged related to psychological distress, showing concern for the support of the family, late bills and deprivation of contact with children due to financial difficulties.

Difficult moments in life, such as unemployment and lack of money to pay all bills. (E43)

Being unemployed, because I have a family to support, and it is very bad to see that they need food, clothes, shoes for our children and not being able to give. (E45) 
When analyzing the conjuncture of the reports of depressive participants, they reported symptoms compatible with the feedback of the depressive condition, evidenced by the speeches based on energy loss, guilt ideation, automatic negative thoughts, and social isolation.

I see that depression in people's lives makes nothing meaningful, so we don't see a future anymore and we just want to stop it, then Ijust thought about taking my life, because I thought it would be better that way and for everyone. (E1)

Depression is a disease that destroys people inside, nothing makes sense in living. You don't feel like smiling, talking. We have no desire to do anything. Not things we did every day, small things. It is very sad to go through all this, so it makes you want to die, to disappear, for you ... there are these bad things that happen to us. (E14)

I understand that when we feel in a dead end, sad, desperate and see no hope of improvement, the idea of ending everything does arise. (E19)

What makes me depressed is everything ... my inability to feel like doing nothing, not taking medication, not wanting to see anyone, feeling lonely. (E38)

Depression is thinking about the things you have done, why you did it and how much time I lost for nothing. I really wanted to go back in time and correct my mistakes. I don't think I'm capable, I feel inside a bladder and I can't get out. (E50)

I get depressed when I lock myself at home a lot without contact with other different people. (E62)

There were also speeches that revealed the lack of ability to experience frustrations throughout life.

If things don't go the way I want, I look really bad. Then I get depressed. (E44)

When I want things and I can't. When I want to have one and I can't do it either, I feel bad. (E49)

What makes me depressed is when I can't get the things I want and solve my problems. (E70)

Some participants listed problems with spirituality, showing the association that when there is a loss of spirituality and its connection with the divine, difficulties emerge from it.

What makes me depressed is when, unintentionally, I turn away from God. (E66)

Something diabolical, inexplicable, painful and that I don't intend to return to ever again. You lose faith, and the devil takes over your life. (E40)

Depression is not of God. It only leads us to evil. When a person is not with God, he ends up falling into this desire to kill himself and end his own life, because he thinks that, by killing himself, all the problems and difficulties are over. (E54)

\section{Thematic unit 2 - Perception of protective factors for depres- sive symptoms and suicidal behavior}

As for the participants' perception of the protective factors for depressive symptoms, reports emerged referring mainly to the importance of healthy family and emotional ties and relationships, social contact, and exercise of faith.

The speeches related to the family and affective relationships as protective factors exposed the need for harmonious coexistence between family members, children present in daily coexistence, pleasant relationship with the partner, family stability and being able to provide for the family.

I am happy when everything is fine, and I can be fine with the family. (E5)

I'm happy when my family is stabilized. (E37)

When I can help my husband with the bills ... (E49)

Regarding the perception of spirituality, it was described in the form of faith in God, daily strengthening of faith, attending masses among others - something that removes or alleviates depression and suicidal ideation.

Istand firm with God and in faith and I use medicines correctly... (E1)

What makes me happy is going to church. It gives me pleasure. (E21)

The will to live, to have God in my heart, healthy life, not to care what others say, I believe it is the best way to be happy. Being well with yourself and everyone around you transmits good mood. (E26)

\section{Thematic category 2 - Participants' perception of the relationship between depressive symptoms and suicidal behavior}

Participants reported their perception of the relationship between depressive symptoms and suicidal behavior, allowing them to ascertain their knowledge about it, and we found that the content expressed referred to personal experiences, which are based on the severity of depression and feelings of hopelessness, psychiatric comorbidities (panic syndrome and anxiety disorder), which triggered or worsened suicidal behavior.

In the speeches, it is clear the sense of development of the depressive condition and its relationship with suicidal behavior, that death is the solution in the face of the intense psychological suffering triggered by the symptoms experienced.

I feel depression, it's a disease that has no meaning, people judge, but they don't imagine how difficult it is, it ends up with us day by day. The desire to kill oneself is because the person feels that it would be a relief, the end to the disease, which actually ends up being the end of many people's lives. (E2)

Depression is a devastating disease that wipes out the person who is depressed and the people who live with the depressive. Everything becomes difficult, everything complicated. It makes you want to lock yourself in a dark room and never leave that place until you die and give no more suffering to anyone. (E13) 
Depression is an unexplained thing. I don't know how to speak; I think there is no solution. When I am very strong as I am, with only a pessimistic thought, I think it is not worth living anymore because I have no pleasure in enjoying anything outside my room. I just want to be locked up and thinking it might be different if my son hadn't killed himself. I know I have another child and it shouldn't be like that, because he also depends on me, but I can't, I'm trying, but, every day that passes, I get sadder and more eager to die. I can't get out of it, I live on medication to sleep. (E7)

I think depression is when a person loses self-love; and when that happens, the person sinks, and there is a desire to kill himself. (E43)

Depression is a weakness, a human failure; and, when he is weak and fails, there is a desire to take his own life as a form of relief. (E66)

\section{DISCUSSION}

The relationship between loneliness, depression and suicidal behavior is described in the literature since loneliness and depression are a debilitating psychological condition, characterized by a profound feeling of social isolation, emptiness and personal threat, as it consists of a distressing and unpleasant feeling, which accompanies the perception that social needs are not met by the quantity or quality of existing relationships, such as the participants who reported loneliness and depression for not having contact with family members or significant people ${ }^{(1-2)}$, to favor suicidal behavior. The need to establish contact with other people is one of the strongest and most constant human impulses, linked to feelings of inclusion, control and affection. This social interaction with other human beings is extremely important for the person to develop and survive in a psychically healthy way, since it generates in them the feeling of belonging ${ }^{(1,3)}$.

Another important fact to be discussed is the feedback that loneliness promotes in depressive conditions, since it is one of the factors related to the onset and worsening of depressive symptoms and that also greatly worsens the feeling of depression of those who already have the disorder in progress ${ }^{(1,6)}$, as well as deficits in social skills ${ }^{(1,9)}$. Guilt not properly treated becomes an important triggering factor for depressive symptoms and suicidal ideation, as it brings negative thought patterns $s^{(1,6,9)}$. When it comes to feedback from depressive symptoms, depressed individuals tend to experience frustrations with intense psychological distress, to worsen the situation of depression installed ${ }^{(9)}$. Still, it is understood that, when the individual is already depressed, there may be an increase in the intensity of these symptoms, which, in turn, worsens the general picture of his perception in the face of depression, that is, there is feedback from the picture ${ }^{(3,10)}$.

Regarding the relationship between rejection and depression, the feeling of rejection or the fear of being rejected is one of the strongest and most painful experiences that people face during their life and has the power to compromise quality of life ${ }^{(1,9)}$. We also emphasize that, through the scales, we had one third of the participants over 61 years old with depressive symptoms, and more than half of them reported pre-existing diseases, such as diabetes mellitus, systemic arterial hypertension and heart disease, repetitive traumatic experiences, chronic stress states (emotional or physical or both), emotional losses, material losses, emotional rejection, relationships between parents and children or between spouses with disruptive dynamics, unemployment, social isolation, among others. All of this is compatible with the literature on the relationship between aging and rejection, since, at present, aging is associated with disease and loss, related to the deterioration of the body, decline and disability, which creates the basis the rejection or uncritical exaltation of old age, for the representation of death, illness, withdrawal and dependence ${ }^{(1-2,10)}$.

As for the relationship between frustrations experienced throughout life, sadness and depression, frustration is a universal and common occurrence for all people aware of the conditions of their existence: it is something necessary for maturation and, consequently, for the development of personality, the individual's relationship with the world, with their reality, with others and with themselves ${ }^{(11)}$. The problem appears when such frustration triggers chronic sadness and ideation of guilt, which is clearly related to depressive symptoms and suicidal ideation ${ }^{(1,11)}$. In the relationship between sadness triggered by low self-esteem and depressive symptoms, the evidence indicates that, in depression, the participant makes constant negative evaluations of himself, the world and the future ${ }^{(12)}$.

On the issue of the perception of depressive symptoms linked to problems in family relationships, the participant's interaction with family members who use alcohol and drugs is exhausting, serving as a trigger for depressive conditions ${ }^{(13)}$. Conjugal conflicts, conflicting relationships, lack of support from the partner and marital dissatisfaction also have an important relationship with high rates of depression and, consequently, suicidal behavior ${ }^{(14)}$.

As for affective losses, these are traumatic events experienced by participants throughout their lives and need time to be elaborated, but there are situations in which they become more traumatic to those who experience them, such as the death of family members by suicide and murders, which end up accentuating the intensity of trauma and psychological distress ${ }^{(14-15)}$. The affective losses related to the death of family members by suicide trigger feelings of guilt and internal questions in the bereaved, without logical answers, and the strong social stigma often dominates the imaginary of people close to the suicidal person, leading to intense psychological suffering ${ }^{(15)}$.

The perception of the individual who cannot bear the frustrations of everyday life, as occurs in affective relationships, becomes a fertile field for the installation of depressive symptoms ${ }^{(14)}$.

With regards to the perception that unemployment triggers depression, this relationship is well established in the literature, in which there is a causal relationship of prolonged unemployment, loss of economic and social status, extreme poverty and food insecurity with chronic depressive states as well as crises of severe depression and suicidal behavior ${ }^{(1-3)}$. In our study, we saw in the participants, significantly, unemployment associated with low family income (between two and five minimum wages). A study carried out showed that people with income below three minimum monthly wages or unemployed had about $70 \%$ higher occurrence of depression compared to those with higher income ${ }^{(16)}$. We emphasize that most participants with depressive symptoms detected by the psychometric scales reported being without income or with an income of up to two minimum wages.

There is a question for those who have a strong sense of religiosity that withdrawing from God generates punishments, 
such as physical and psychological diseases, such as depression and, consequently, suicidal behavior ${ }^{(17)}$.

Regarding the perception of the participants about the protective factors for depressive symptoms and suicidal behavior, the family emerged as a matrix of social experience and a school for the formation of affective bonds that occupies in the psyche of the participants of this block the core of which the existential meaning emanates and the emotional well-being depends on ${ }^{(18)}$. Studies indicate that individuals with better social or family support would be less predisposed to suffering or mental disorders when subjected to stressful events ${ }^{(3,18-19)}$; authors state that families in which there is encouragement to talk about the problems of their members and more open to changes in opinion have more protective aspects in relation to the occurrence of depression and, in turn, suicide ${ }^{(18)}$. This is because such families meet the prerequisites of having someone reliable to talk about daily difficulties and feelings, allowing them to be welcomed and personal growth ${ }^{(19)}$.

As for the question of the perception of spirituality, studies point to the relationship between spiritual well-being and minor mental disorders; and concluded that spirituality/religiosity was a factor inversely correlated with psychic disorders, such as mild depressive $e^{(1,3,17)}$. Religiosity and spirituality offer a sense of purpose and existential meaning and an important weapon of resilience to suffering ${ }^{(17)}$. Participants were unanimous in recognizing the protective role of spirituality or religion; and, in this sense, neuroscience points out that the daily practice of prayer or meditation or mystical contemplation positively alters brain neurochemistry, promoting feelings of peace, security, protection and love ${ }^{(20)}$.

There were consensual reports from the participants about the relationship between depressive symptoms and suicidal behavior. Studies show that the difficulty of adequate perception of the causes of depression and the lack of internal emotional resources to deal with stressful and difficult situations are characteristics of depressive individuals and worsen according to the intensity of the condition, causing alteration in self-criticism and worsening of the feeling of psychological distress ${ }^{(1-2,6)}$. As these individuals delay seeking care, they then worsen, with a considerable increase in the chances of the appearance of suicidal behavior ${ }^{(6)}$.

Regarding death being verbalized as a solution to the intense psychological suffering triggered by the symptoms experienced, it should be noted that such a prospect of death appears in moderate and severe depression ${ }^{(3)}$. Among the characteristic feelings of severe depression, we have the feeling of helplessness towards life and that there is no way out of the psychological agony suffered, and this is a trigger for suicidal behavior ${ }^{(1-3)}$.

As for the relationship between hopelessness and suicidal behavior, this is understood as an important risk factor ${ }^{(1)}$, as it is configured by self-defeating thoughts and a pessimistic and negative view of the future, being linked to depression ${ }^{(18)}$. What we observed in the participants of our study is the intense effect that the absence of meaning or purpose in life causes, with its corrosive impact on the emotional, cognitive and behavioral state, to corroborate a study ${ }^{(20)}$. On the other hand, the association between anxiety disorders and depression is well known ${ }^{(1-3)}$ : research has shown that, on average, $70 \%$ of individuals with depression suffer from anxiety concomitantly and about $80 \%$ of those who have anxiety present a picture associated with depression ${ }^{(16,20)}$, since they form a feedback loop between anxiety and depression, serving as a trigger for hopelessness and the desire to die.

\section{Study limitations}

The limitation of this research refers to the fact that it portrays the reality of only this sample (municipality of Poços de Caldas/ MG), so that it is not possible to generalize the data.

\section{Study contribution}

The data are pioneering: they present the panorama of depressive symptoms and its relationship with suicidal behavior in an adult population in Poços de Caldas/MG, which will allow municipal managers to carry out planning to face the issues addressed.

\section{FINAL CONSIDERATIONS}

The participants' perception of risk factors was linked to family problems, sadness, loss of emotional relationships, unemployment, loneliness, and inability to experience frustrations; and protection, related to family and spirituality. The family was pointed out for both risk and protection factors, demonstrating its influence as a source of mutual support, security and affection. There was a relationship between depressive symptoms and suicidal behavior.

\section{ACKNOWLEDGMENT}

The Coordination for the Improvement of Higher Education Personnel (CAPES) for the doctoral scholarship awarded during the research.

\section{REFERENCES}

1. World Health Organization (WHO). Suicide in the world: global health estimates [Internet]. Brussels, 2019[cited 2020 Dec 27]. Available from: https://apps.who.int/iris/bitstream/handle/10665/326948/WHO-MSD-MER-19.3-eng.pdf?ua=1

2. World Health Organization (WHO). Preventing Suicide: a global imperative [Internet]. Brussels, 2014[cited 2020 Dec 27]. Available from: https://www.who.int/mental_health/suicide-prevention/world_report_2014/en/

3. American Psychatric Association (APA). Diagnostic and statistical manual of mental disorder, Fifth Editon (DSM - V). Washington: DC; 2015. 948p.

4. Güngör BB, Akgül Al, Taymur İ, Demirci H, İnel A. Evaluation of eating attitudes, anger and impulsivity in atypical and non-atypical depression and assessment of comorbidity of binge eating. Psychiatr Danub. 2020;32(1):105-14. https://doi.org/10.24869/psyd.2020.105 
5. Marcolan JF. Pela política pública de atenção ao comportamento suicida. Rev Bras Enferm. 2018;71(Suppl 5):2343-2347. https://doi. org/10.1590/0034-7167-2018-0256

6. Marcolan J, Silva D. O comportamento suicida na realidade brasileira: aspectos epidemiológicos e da política de prevenção. Rev M. Estud Morte. 2019;4(7):31-44. https://doi.org/10.9789/2525-3050.2019.v4i7.31-44

7. Bardin L. Análise de conteúdo. São Paulo: Edições 70; 2011. 229 p.

8. Instituto Brasileiro de Geografia Estatística (IBGE). Estimativas populacionais para os municípios brasileiros em 01-07-19, 2019. Available from: https://biblioteca.ibge.gov.br/visualizacao/livros/liv100923.pdf

9. Barroso SM, Andrade VS, Midgett AH, Carvalho RGN. Evidências de validade da Escala Brasileira de Solidão UCLA. J Bras Psiquiatr. 2016;65(1):68-75. https://doi.org/10.1590/0047-2085000000105

10. Azeredo ZAS, Afonso MAN. Solidão na perspectiva do idoso. Rev Bras Geriatr Gerontol. 2016;19(2):313-24. https://doi. org/10.1590/1809-98232016019.150085

11. Bolsoni-Silva A, Loureiro S. Anxiety and depression in Brazilian undergraduate students: the role of sociodemographic variables, undergraduate course characteristics and social skills. CJAST. 2015;5(3):297-30. https://doi.org/10.9734/BJAST/2015/13004

12. Muscatell KA, Dedovic K, Slavich GM, Jarcho MR, Breen EC, Bower JE, et al. Neural mechanisms linking social status and inflammatory responses to social stress. Soc Cogn Affect Neurosci. 2016;11(6):915-22. https://doi.org/10.1093/scan/nsw025

13. Senicato C, Azevedo RCS, Barros MBA. Transtorno mental comum em mulheres adultas: identificando os segmentos mais vulneráveis. Ciênc Saúde Colet. 2018;23(8):2543-54. https://doi.org/10.1590/1413-81232018238.13652016

14. Costa FA. Mulher, trabalho e família: os impactos do trabalho na subjetividade da mulher e em suas relações familiares. Rev Pret. 2018;3(6):434-52. Available from: http://periodicos.pucminas.br/index.php/pretextos/article/view/15986

15. Marback RF, Pelisoli C. Terapia cognitivo-comportamental no manejo da desesperança e pensamentos suicidas. Rev Bras Terap Cognit. 2014;10(2):122-9. https://doi.org/10.5935/1808-5687.20140018

16. Benach J, Vives A, Tarafa G, Delclos C, Muntaner C. What should we know about precarious employment and health in 2025 ? framing the agenda for the next decade of research. Int J Epidemiol. 2016;45(1):232-8. https://doi.org/10.1093/ije/dyv342

17. Avelar-González AK, Bureau-Chávez M, Durón-Reyes $D$, et al. Spirituality and religious practices and its association with geriatric syndromes in older adults attending to a geriatric's clinic in a university hospital. J Relig Health. 2020;59:2794-806. https://doi.org/10.1007/ s10943-020-00990-0

18. Santos WS, Ulisses SM, Costa TM, Farias MG, Moura DP. A influência de fatores de risco e proteção frente à ideação suicida. Psicol Saúde Doença. 2016;17(3):515-26. https://doi.org/10.15309/16psd170316

19. Bernard R, Sabariego C, Cieza A. Difficulties encountered by people with depression and anxiety on the web: qualitative study and webbased expert survey. J Med Internet Res; 21(10):e12514. https://doi.org/10.2196/12514

20. Shao R, He P, Ling B, Tan L, Xu L, Hou Y, et al. Prevalence of depression and anxiety and correlations between depression, anxiety, family functioning, social support and coping styles among Chinese medical students. BMC Psychol. 2020;8:38. https://doi.org/10.1186/ s40359-020-00402-8 